\title{
The Dominion model of transitional constitutionalism
}

Mara Malagodi, ${ }^{*}$ Luke McDonagh, ${ }^{* *}$ and Thomas Poole ${ }^{* * *}$

(Pre-proof version)

This symposium has explored New Dominion constitutionalism inductively and contextually, placing the phenomenon within a historically nested set of ideas and practices from the Old (Settler) Dominions, through the "Bridge Dominion" of Ireland, before giving detailed attention to the South Asian New Dominions of India, Pakistan, and Ceylon (now Sri Lanka). The articles collectively form a basis from which to analyze the legal configuration of New Dominion status and its legacy by exploring links between New Dominion constitutional framing and post-independence design and practice. Building on the case studies, the principal contention of this summative contribution is that New Dominion constitutionalism should be understood as the first constitutional model of note designed to manage political transitions on a global scale. A product of the twilight of the British Empire, New Dominion constitutionalism represents a model for decolonizing nations and an important antecedent to later postCold War transitions. Both transitional and transnational, New Dominion status offered an interim frame of government for political transitions, the fuzzy center of which derived from Westminster-style conventions of political constitutionalism, as well as a template establishing the legal basis for constituting the fully independent state.

\section{Introduction}

New Dominion constitutionalism can be reasonably characterized as the first interim constitutional model of note designed to manage complex political transitions on a

\footnotetext{
* Assistant Professor of Law, The Chinese University of Hong Kong. Email:mmalagodi@cuhk.edu.hk .

** Senior Lecturer in Law, City, University of London. Email: Luke.mcdonagh@city.ac.uk.

*** Professor of Law, London School of Economics and Political Science. Email: T.M.Poole@1se.ac.uk.
} 
global scale. It refers to the acquisition of responsible government by a handful of nonsettler British colonies through Dominion status, a temporary constitutional arrangement that eventually led to their transformation into republics. A product of the twilight of the British Empire, New Dominion constitutionalism represents a crucial but understudied instrument of decolonization by constitutional means, which was expressly designed to be provisional, and an important antecedent to later post-Cold War transitions on which academic literature has tended to focus. ${ }^{1}$

This symposium issue has analyzed the legal concept of Dominion status contextually, placing it within a historically nested set of ideas and practices from the Old (Settler) Dominions, ${ }^{2}$ through the "Bridge Dominion" of Ireland, ${ }^{3}$ before giving detailed attention to the New Dominions of India, ${ }^{4}$ Pakistan, ${ }^{5}$ and Ceylon (now Sri Lanka). ${ }^{6}$ This article analyzes the legal configuration of New Dominion constitutionalism alongside the political concomitants that gave rise to it, and assesses the afterlife of this constitutional model in the above jurisdictions. Although the notion of Dominion fell into disuse by 1953, it became reincarnated into the model of Commonwealth Realm through which the majority of the remaining British colonies in Asia, Africa, and the Caribbean's acquired independence. ${ }^{7}$

\footnotetext{
${ }^{1}$ For recent work on post-Communist and post-conflict constitutional transitions, see ANDREW ARATO, POST-SOVEREIGN CONSTITUTION-MAKING (2016); ConstitutionMaking and Political Settlements in Times of Transitions 6(1) GLOBAL CONSTITUTIONALISM (SPECIAL ISSUE) 1 (2017).

${ }^{2}$ Canada (1867), Australia (1901), New Zealand (1907), Newfoundland (1907), South Africa (1910). See Peter C. Oliver, "Dominion Status": History, Framework, and Context, 17(4) INT'L J. CONST. L. (2019).

${ }^{3}$ Ireland (1922-1937). See Luke McDonagh, Losing Ireland, Losing the Empire:
}

Dominion Status and the Irish Constitutions of 1922 and 1937, 17(4) INT'L J. CONST.

L. (2019).

${ }^{4}$ India (1947-1950). See Rohit De, Between Midnight and Republic: Theory and Practice of India's Dominion Status, 17(4) INT'L J. CONST. L. (2019).

5 Pakistan (1947-1956). See Mara Malagodi, Dominion Status and the Origins of authoritarian constitutionalism in Pakistan, 17(4) INT'L J. CONST. L. (2019).

${ }^{6}$ Ceylon (1948-1972). See Rehan Abeyratne, Uncertain Sovereignty: Ceylon as a Dominion, 1948-1972, 17(4) INT'L J. CONST. L. (2019).

7 The African Commonwealth Realms were: Ghana (1957-1960); Nigeria (19601963); Sierra Leone (1961-1971); the Gambia (1965-1970); Tanganyika (1961-1962); Uganda (1962-1963); Kenya (1963-1964); and Malawi (1964-1966). In the Mediterranean, Malta retained this status for a decade (1964-1974). In the Indian and 
Our inquiry into constitutional aspects of decolonization at the twilight of the British Empire assesses the successes and failures of New Dominion constitutionalism and explores the enduring links between the New Dominion constitutional framework and post-independence design and practice in these jurisdictions. While New Dominion constitutionalism successfully helped Ireland and the South Asian colonies transition expeditiously into independence, it fell short of securing an enduring British influence in the newly independent states. The question of success is also linked to the kind of legacy that the transitional New Dominion period and its constitutional structures left behind. The immediate legacy is institutional and is most clearly reflected in the design choices made by the framers of the new republican constitutions crafted to replace the Dominion frameworks. The long-term legacy is harder to trace and points to the divergent political trajectories of these four postcolonial states. While New Dominion constitutionalism arguably succeeded in paving the way to democratization in Ireland and India, Pakistan and Ceylon veered toward frequent bouts of authoritarianism and often violent sectarian politics.

The article proceeds as follows. Section 2 explains the significance of the model of New Dominion constitutionalism in answering comparative questions about constitutional founding moments, constitutional borrowing, and ultimately constitutional decay. Section 3 situates the case studies within a wider historical context, including not only the end of Empire but also the beginning of the Cold War. Section 4 defines New Dominion constitutionalism and isolates ten specific elements of this model at the time of adoption of the Dominion constitution. Fourth, it assesses the degree of success of New Dominion constitutionalism by focusing on the disjuncture between the intended goals of New Dominion constitutionalism from the British perspective - retaining a measure of control over newly independent former

Pacific Ocean, respectively, Mauritius (1968-1992) and Fiji (1970-1987) also adopted transitional constitutional arrangements. In the Caribbean (Antigua and Barbuda, 1981; Bahamas, 1973; Belize, 1981; Dominica, 1978; Grenada, 1974; Jamaica, 1962; Saint Christopher and Nevis, 1983; Saint Lucia, 1979; and Saint Vincent and the Grenadines, 1979) and in the Oceanic islands (Papua New Guinea, 1975; Solomon Islands, 1978; and Tuvalu, 1978), the majority of countries remain Commonwealth Realms to this day, with the two notable exceptions of Guyana (1966-1970) and Trinidad and Tobago (1962-1976). 
colonies - and the aims of local actors, who made use of this transitional model to push for full independence from Britain. In each case British hopes were frustrated, while local actors made different uses of the constitutional tools offered by Dominion status. Finally, it examines the imprint left by the New Dominion constitutional model on subsequent constitutional orders, while accepting that this is very difficult to trace. Not only does this inquiry involve consideration of counterfactuals, and sometimes narratives of denial on the part of the former colonial state, it also raises the question of what function a transitional constitution of the type the model offered ought to perform.

\section{Significance of New Dominion constitutionalism}

New Dominion constitutionalism represents a crucial phase in the history of Ireland, India, Pakistan, and Sri Lanka - a critical juncture that set each jurisdiction onto a particular constitutional trajectory. As such, the adoption and adaptation of Dominion status across these case studies help to explain the different constitutional developments in these jurisdictions after independence and the long-term legacy of this peculiar set of constitutional transitions.

To substantiate the claim that New Dominion constitutionalism represents the first transnational constitutional template for securing transitional change on a global scale, we first observe that the model offered a technique or platform for transforming juridical relations from a condition of subordination to one of equality. This did not always necessarily imply full independence - indeed the Balfour Declaration of 1926, the canonical statement of Dominion status at an earlier stage of development, carefully avoided that term. Old Dominion formulations deliberately left obscure the question of what the colony was transitioning to. Ambiguity had always been a feature of the politics of Dominion status - Prime Minister Lloyd George told the Commons in 1921 that it was "difficult and dangerous to give a definition" of Dominion status ${ }^{8}$ - and

${ }^{8}$ K. C. Wheare, The Constitutional Structure of the Commonwealth 10 (1960). 
could still serve useful transitional functions after $1945 .{ }^{9}$ New Dominion constitutionalism was clearer on the end point - the former colony was en route to full independence (not necessarily immediately), albeit with continued external links to Britain (or so metropolitan officials hoped). As such, New Dominion constitutional instruments were designedly transitional in a way that was not true of their predecessors.

The parameters of our case selection can be explained in light of these issues. Analysis in this symposium issue concentrates on the South Asian "New" Dominions of India (1947-1950), Pakistan (1947-1956), and Ceylon (1948-1972) and their immediate antecedent — the "Bridge Dominion" of Ireland (1922-1937). Attention falls on non-settler British colonies whose self-government-let alone independence London was always reluctant to concede for geostrategic, economic, and cultural reasons but was ultimately forced to accept. The mitigation of the sudden loss of key imperial possessions was a top priority for post-war Britain. ${ }^{10}$ The inevitability and haste of the transition - alongside Britain's attempts to retain some form of control profoundly shaped the constitutional form of Dominion status across these jurisdictions. Contextually, the four case studies acquired self-government in a close temporal sequencing and as such they featured intimate political exchanges and reciprocal influences in their fight for independence. On the one hand, from a domestic perspective, the New Dominions were early but crucial laboratories for the constitutional politics of decolonization and democratization given the common, transnational constitutional basis upon which they had embarked upon their respective journeys as independent nations. On the other hand, from an international perspective, the constitutional configuration of the New Dominions' acquisition of independence

\footnotetext{
${ }^{9}$ Harshan Kumarasingham, The "Tropical Dominions": The Appeal of Dominion Status in the Decolonisation of India, Pakistan and Ceylon, 23 TRANSACTIONS ROYAL HIST. SOC'Y 223, 226 (2013):

"The abstract and nebulous conception of being a Realm and Dominion suited the chaotic situation that Britain and its South Asian possessions found themselves in the 1940s when actions and decisions were needed rapidly." W. David McIntyre, The Strange Death of Dominion Status, 27 J. IMPERIAL \& COMMONWEALTH HIST. 193, 199 (1999): "Dominion status, then, proved a remarkably useful transitional device for speeding independence for India and Pakistan, as it had earlier for the 'old Dominions."”

${ }^{10}$ PHILIP MURPHY, MONARCHY AND THE END OF EMPIRE 34-49 (2013).
} 
radically transformed the nature of the Commonwealth and the legal basis for the acquisition of membership in the critical early years of the Cold War(1949-1953). ${ }^{11}$

One consequence was that the former colonial masters were compelled to design mutually acceptable but destined-to-be-temporary New Dominion constitutions for their former colonies. While written, these documents were-in line with the Westminster model - vague and non-entrenched, with a strong executive at the center, and few robust checks and balances of a legal nature. They were also engineered with a view to retaining a degree of British control and influence over the former colonies for as long as possible. As such, New Dominion constitutions were based on the evolving precedents of the Old Dominions' constitutional frameworks and the historical demands for self-government that had already underpinned the American Revolution. But they were also mediated by the experience of the Irish Free State and reflected the key statutory restrictions to the sovereignty of the Imperial Parliament introduced by the Statute of Westminster in 1931. But the ambiguity surrounding the locus of sovereignty within the New Dominion constitutional framework justified the preoccupations of many anti-colonial leaders with the notion that Dominionhood was a "halfway house" between colonial dependence and full postcolonial independence. Ultimately, the choices made by constitutional actors in the Dominion years had longterm consequences on the processes of state building and constitutional development in each of these jurisdictions.

\section{Historical context of New Domini on constitutionalism}

New Dominion constitutionalism emerges from the ashes of the two world conflicts. World War II may not have produced an immediate sea change in Britain's ambitions -it still aspired to be a "hird force" in world affairs - but it certainly left Britain materially weakened in financial terms and reduced in its geostrategic capacity. In some colonial and former colonial territories, the shared experience of war appeared for a time to consolidate the Empire, but the inability to protect imperial subjects in Southeast

\footnotetext{
${ }^{11} I d$.
} 
Asia and elsewhere had a diminishing effect ${ }^{12}$ that subsequent British imperial failures only served to reinforce.

It was in this wartime and immediately post-war context that the principle of self-government was conceded for the colonial Empire (the timing of which usually remained unclear). Subsequent moves in the direction of independence for colonial territories, some of which this symposium has tracked, were contained within an updated vision of the Anglosphere. As Duncan Bell has observed, almost all "midcentury projects regarded the 'Anglo' powers as a nucleus or vanguard" of the new global order. Although initially a product of the late Victorian period, ${ }^{13}$ the idea of a multinational commonwealth gained ground, eclipsing the Seeleyan vision of a global nation state. ${ }^{14}$ The Balfour Declaration, drafted at the Imperial Conference in 1926, had sought to recast the bilateral connection between Britain and the various (Old) Dominions as an intimate form of international association based on "free association," though it studiedly avoided the term "independence." 15 "The old club [would] become a rules-based association"16 held together through informal ties of sentiment and selfinterest. ${ }^{17}$ Proponents envisaged the Empire transfigured with the help of new technologies into something else, a vast political-economic unit, whether a federation, transcontinental state, or multinational commonwealth, that would offer stability and leadership to the world. ${ }^{18}$ Dominionhood represented another instantiation of the idea of Greater Britain, one in fact significantly more tangible than most. ${ }^{19}$

12 Keith Jeffrey, The Second World War, in THE OXFORD HistORY OF THE BRITISH EMPIRE: THE TWENTIETH CENTURY 326 (Judith M. Brown \& William Roger Louis eds., 1999).

${ }^{13}$ DUNCAN BELl, ED., VictORIAN ViSIONS OF GLOBAL EMPIRE (2007).

${ }^{14}$ DUNCAN BELL, REORDERING THE WORLD: ESSAYS ON LIBERALISM AND EMPIRE 188 (2016).

${ }^{15}$ PHILIP MURPHY, MONARCHY AND THE END OF EMPIRE: THE HOUSE OF WindSOR, THE BRITISH GOVERNMMENT, AND THE POSTWAR COMMONWEALTH 17 (2013).

${ }^{16}$ DAVID MCINTYRE, A GUIDE TO THE CONTEMPORARY COMMONWEALTH 69, 77 (2001).

17 JOHN DARWIN, THE EMPIRE PROJECT: THE RISE AND FALL OF THE BRITISH WORLDSYSTEM 407 (2011).

${ }^{18}$ DUNCAN BELL, THE IDEA OF GREATER BRITAIN: EMPIRE AND THE FUTURE OF WORLD ORDER, 1860-1900 (2007).

${ }^{19}$ Seminal texts include JoHn ROBERT SEELEY, THE EXPANSION OF ENGLAND: TwO COURSES OF LeCTURES (1883); CHARles DilKe, GREATER BRITAIN (1868); J. A. Froude, OCEANA, OR ENGLAND AND HER COLONIES (1907); L. T. HOBHOUSE, DEMOCRACY AND REACTION (1904). 
Allowing for some variation across the political spectrum, ${ }^{20}$ the central aim of British imperial policy immediately after 1945 was to move all but the smaller isolated colonies into self-government as soon as possible (though that was not expected to be all that soon) and, in doing so, to consolidate links with Britain on a permanent basis. ${ }^{21}$ Taking Balfour and the Statute of Westminster 1931 into the next generation, New Dominion constitutionalism was to act as the "midwife for decolonization."22 It offered a legal platform intended to facilitate a strategic goal: the aim being not to get rid of the Empire altogether so much as to reimagine it, the logic being that "if we treat them strictly as a[n] [independent] dominion, they will behave very like a loyal colony."23

The conjunction of imperial nationalism and a Britannic Commonwealth held together by bonds of affection was not quite as quixotic as it now appears. The existence in the interwar period of self-governing "British" states on three continents outside Europe lent a degree of substance to the conceit that the British were a "world people" uniquely adapted to the founding of new nations. ${ }^{24}$ That this was not a straightforward case of imperial delusion is supported by the operational effectiveness of this looser Britannic version of empire up to 1945, the lion's share of which ${ }^{25}$ just about keeping together on the strength of old links forged through money, through trade, and in war. The subsequent dismantling of so diverse and far-flung an empire was always likely to be messy, but whatever the outcome the results would be presented to the public as the consequence of British policy. "History would record a commitment to self-

${ }^{20}$ On the domestic critics of empire, see GREGORY CLAEYS, IMPERIAL SCEPTICS: BRITISH CRITICS OF EMPIRE 1850-1920 (2010).

${ }^{21}$ Ronald Hyam, Bureaucracy and 'Trusteeship' in the Colonial Empire, in THE OXFORD HISTORY OF THE BRITISH EMPIRE: THE TWENTIETH CENTURY 276 (Judith M. Brown \& William Roger Louis eds., 1999).

22 TIMOTHY M. SHAW, COMMONWEALTH: INTER- AND NON-STATE CONTRIBUTIONS TO GLOBAL GOVERNANCE 24 (2008).

${ }^{23}$ Memo by Patrick Gordon Walker, Parliamentary Under-Secretary of State at the Commonwealth Relations Office, March 1948, quoted in DARWIN, supra note 18, at 561.

${ }^{24}$ Id. at 392.

${ }^{25}$ Obvious exceptions being South Africa, weakest link among Old Dominions, and Ireland, explored in Luke McDonagh, Losing Ireland, Losing the Empire: Dominion Status and the Irish Constitutions of 1922 and 1937, 17(4) INT'L J. CONST. L. (2019). . 
government that had been planned and fulfilled. The British aimed to control their own destiny, presiding if possible over the rebirth of the Imperial system rather than its dissolution." 26

The Dominion concept, reliant on convention and bilateral negotiation, always contained a strong element of plasticity that often proved useful in managing acute tensions, a point highlighted in each of our case studies. Nonetheless, somewhere near its core the concept reflected a "distinctive blend of national status and Imperial identity" and rested on a belief strongly held in the metropolis that in colonial societies without a common culture, adherence to British institutions and ideas was the most plausible foundation for nation building. ${ }^{27}$ The idea seemed to be that a loose but not content-less constitutional form lent itself to the inculcation of a particular culture or style of constitutional politics, which in turn lent itself to the maintenance of close material, cultural, and political ties with the former colonial power.

Our four jurisdiction-specific studies - Ireland, India, Pakistan, Ceylon—show how far from reality such hopes lay. The practical instantiation of the New Dominion model varied considerably from jurisdiction to jurisdiction, yet the case studies reveal a consistent story of the loss of imperial control. We must acknowledge here the significance both of race and of "national liberation" movements in each territory. In its earlier iteration, Dominion status had been reserved for the "white" settler colonies - Ireland remained something of a case apart ${ }^{28}$ — and as such fitted neatly with generally held assumptions about European civilizational superiority. ${ }^{29}$ The more densely plural nature of post-1945 arrangements made New Dominion

${ }^{26}$ William Roger Louis, The Dissolution of the British Empire, in THE OXFORD HISTORY OF THE BRITISH EMPIRE: THE TWENTIETH CENTURY 329 (Judith M. Brown \& William Roger Louis eds., 1999).

27 John Darwin, A Third British Empire? The Dominion Idea in Imperial Politics, in THE OXFORD HISTORY OF THE BRITISH EMPIRE: THE TwENTIETH CENTURY 85 (Judith M. Brown \& William Roger Louis eds., 1999).

${ }^{28}$ Donal Lowry distinguishes Ireland by calling it the "Captive Dominion": The Captive Dominion: Imperial Realities behind Irish Diplomacy, 1922-49, 36 IRISH HIST. STUD. 202 (2008).

${ }^{29}$ These assumptions were held by liberals as well as conservatives. See, e.g., KARUNA MANTENA, ALIBIS OF EMPIRE: HENRY MAINE AND THE ENDS OF LIBERAL IMPERIALISM (2010); Cheryl Welch, Colonial Violence and the Rhetoric of Evasion, 31 POL. THEORY 235 (2003). 
constitutionalism more complicated in race terms. In fact, some soon-to-be-former colonies had reservations about the racial assumptions bound up with Dominionhood, and some rejected it partly on that basis, while others saw it as the clearest path to independence. ${ }^{30}$

The Old Dominion model was initially framed with an expectation that though (internal) legal sovereignty was being transferred, the settler Dominions would remain British (or at least Britannic) not just culturally and socially but also in terms of trade, commerce, and military cooperation. It was taken for granted that the white or settler colonies would adapt over time to the Westminster-derived constitutional model. The opposite supposition tended to be made about the prospect of self-rule in territories such as India and Ceylon - and also Ireland, whose example acts as a point of disruption within the Dominion narrative. True, the Dominion model had been successfully applied there, even though it was only accepted in 1922 as a compromise; the ambiguity of the Old Dominion model once more proving its worth in squaring the circle between the aims and objectives of the British government and Irish nationalists. Yet the very success of Irish self-rule after 1922 also tended to disprove previously held assumptions about the unsuitability of the Irish for self-government. The Dominion experience in Ireland acted as an aversive as well as aspirational example,,${ }^{31}$ and showed how it was possible to treat the Dominion constitution in a rough and ready way to secure a nationalist agenda determined by local elites. From the British perspective, although Ireland was an imperfect case, the bridge now existed to transform the Old Dominion model into the new one.

\section{Fundamental elements of New Dominion constitutionalism}

30 Burma was given the choice of whether or not to stay within the British Commonwealth system but decided in 1947 to break the tie with Britain, becoming a sovereign and independent republic in January 1948. The Sudanese and Egyptians were also among those who believed that the phrase "Dominion status" implied further British domination. Louis, supra note 27, at 337-338, 341.

${ }^{31} \mathrm{Kim}$ Lane Scheppele, Aspirational and Aversive Constitutionalism: The Case for Studying Cross-Constitutional Influence Through Negative Models, 1(2) INT'L J. CONST. L. 296 (2003). 
Both transitional and transnational, New Dominion status offered an interim frame of government for political transitions, the fuzzy center of which derived from Westminster-style conventions of political constitutionalism, as well as a template establishing the legal basis for constituting the fully independent state. New Dominion constitutions facilitated the execution of government functions through structures developed across the boundaries of distinct political units: the United Kingdom on one hand, and the Dominions on the other. These legal structures are not easy to disentangle from a normative perspective, as they contain elements of both imperial and postcolonial institutions and principles. ${ }^{32}$

At a basic level, however, New Dominion constitutionalism represents a modality of decolonization by constitutional means. Though distinctive, the model remains consonant with the deep structure of British constitutionalism. True, the model's emphasis on explicit and detailed constitutional design at first sight seems rather alien to that tradition. But we should remember that by the mid-twentieth century British jurists, officials, and statesmen had accrued decades of experience in writing constitutional texts outside the metropolitan sphere. "A year never passes without several Constitutions or constitutional amendments being produced, mostly by the Colonial Office," Ivor Jennings and C. M. Young wrote in 1938. "It may indeed be said that while the British choose to live under an 'unwritten' Constitution, they are by far the most prolific makers of written Constitutions - for others." ${ }^{33}$

In this vein, British jurists and officials of the period generally formed the view that the British system of government not only provided a superior model but also this model could be exported to former colonies to help develop self-governing institutions and the normative environment needed to sustain them. ${ }^{34}$ This differs from earlier juristic attitudes. In Victorian England, appreciation of the British constitutional Sonderweg often produced the opposite conclusion on the viability of transnational constitutional transplants. A. V. Dicey, for instance, writing under the influence of

${ }^{32}$ Chris ThORNHILl, A SOCIOLOGY OF TRANSNATIONAL CONSTITUTIONS 2 (2016).

${ }^{33}$ W. IVOR JENNINGS \& C. M. YOUNG, CONSTITUTIONAL LAWS OF THE BRITISH EMPIRE 25 (1938).

${ }^{34}$ See, e.g., W. IVOR JENNINGS, THE APPROACH TO SELF-GOVERNMENT 1-24 (1958). 
Maine ${ }^{35}$ opined at the turn of the century that it was "in the highest degree doubtful how far English institutions can with success be transplanted to countries of which the development has been utterly different from the exceptional history of England." 36

As a result, features of New Dominion constitutionalism replicate essential elements of traditional British constitutional praxis. The model is predicated on the idea of gradual and managed change, allied to a thoroughgoing pragmatism at the level of both conception and execution, ${ }^{37}$ and seeks to normalize exceptional situations through the deployment of legal techniques. ${ }^{38}$

Commentators tend to focus on the pragmatic and flexible nature of the New Dominion constitutional framework. Our case studies indeed reveal considerable variety across territories - even within the same region - in the way the Dominion constitutional framework was adapted to suit local circumstances. And it is impossible to understand the constitutional politics of Dominion status without acknowledging the significance of gaps and ambiguities in the relevant documents and legal arrangements. ${ }^{39}$ But it remains the case that the New Dominion model can be characterized as a "constitutional matrix" with a baseline common to all the jurisdictions in which it was deployed. As such, it both favored and encouraged the development of certain forms of institutional politics. As an expression or derivation of British constitutional principles, we can identify ten core elements of the New Dominion model that together represent a "snapshot" of that constitutional form at the time Dominion status was granted and accepted. The first three relate to government structures, the next four go to the Dominion's relationship with Britain, while the last three capture more specifically transitional features.

\section{Responsible government:}

${ }^{35}$ Dylan Lino, Alfred Venn Dicey and the Constitutional Theory of Empire, 36 OXFORD J. LEGAL STUD. 751, 764-765 (2016).

${ }^{36}$ A. V. Dicey, Will the Form of Parliamentary Government Be Permanent? 13 HARV. L. REV. 67, 71 (1899(.

${ }^{37}$ MARTIN LOUGHLIN, PUBLIC LAW AND POLITICAL THEORY ch. 4(1992).

${ }^{38}$ ThOMAS POOLE, REASON OF STATE: LAW, PREROGATIVE AND EMPIRE (2015).

${ }^{39}$ For analysis of vagueness as a general feature (and virtue) of constitutions, see Timothy Endicott, The Value of Vagueness, in VAGUENESS IN NORMATIVE TEXTS (Vijay K. Bhatia, Jan Engberg, Maurizio Gotti, \& Dorothee Heller eds., 2005). 
The New Dominion constitutional framework was centered on a directly or indirectly elected Parliament, ${ }^{40}$ thus substantiating the meaning of independence in institutional terms under the Dominion constitution. The belief in the validity and effectiveness of a Westminster-derived majoritarian parliamentary form of government was such that alternative proposals, such as an element of consociationalism in Ceylon that may have secured minority interests, were roundly rejected. In Ireland and Pakistan, the Dominion Parliament's dual role as legislator and Constituent Assembly proved problematic. The flexible nature of Westminster-derived New Dominion constitutionalism, which emphasized political rather than legal controls, often failed to hold the executive to account during the transitional period. Parliamentarism could readily amount in this context to elective dictatorship (e.g. Pakistan).

\section{Strong central executive:}

New Dominion constitutions created a strong executive at the center, featuring extensive prime ministerial (prerogative) powers but having its chief institutional expression in Cabinet government. Indeed, part of the reason local leaders (e.g. in India) instrumentally accepted Dominion status was because of the transformative potential inherent in a flexible constitutional framework in which power was streamlined and centralized. We have seen this potential utilized in all four jurisdiction-specific case studies to consolidate power at the center and advance a centripetal state-building process led by political elites.

\section{Independent, but deferential judiciary:}

New Dominion constitutions emphasized the centrality of the rule of law, initially based on a British or Diceyean model, guarded by an independent judiciary and given shape through a non-entrenched constitution almost entirely devoid of

\footnotetext{
${ }^{40}$ The British constitutional tradition was more comfortable with unitary states than with federal structures. Dicey thought that the constitutional rigidity typically necessitated by federalism was ill-suited to the demands of imperial rule. For him, federalism "meant both weak and conservative government." See Lino, supra note 36, at 769 .
} 
justiciable fundamental rights. ${ }^{41}$ Although the New Dominion courts quickly developed powers of judicial review of executive action, ${ }^{42}$ the immediate bequest of British constitutionalism tended to be courts that deferred to the political branches of state on constitutional matters (e.g. The State (Ryan) v. Lennon ${ }^{43}$ in Ireland, the Tamizuddin litigation ${ }^{44}$ in Pakistan, and cases on illiberal legislation in Ceylon in 1948, 1949, and 1956). Constitutional litigation during the Dominion period revealed the existing gulf between substantive and procedural understandings of the rule of law across the various jurisdictions. ${ }^{45}$

\section{Legal basis:}

It is perhaps notable that the legal basis of all New Dominion constitutions rested on an Act of the Imperial Parliament. Although different routes were adopted, all the New Dominion legal structures remained sufficiently open to accommodate the agency of local political actors in the transition. A lesson was learned from the Bridge Dominion - the Irish Free State Constitution Act 1922 included as a schedule the document drafted by the Third Dáil to serve as Ireland's Dominion constitution. Later, the India Independence Act 1947 amended the Government of India Act 1935 so that it could serve as India and Pakistan's Dominion constitutions and gave statutory basis to their respective Constituent Assemblies; and the Ceylon Independence Act 1947 allowed the Colonial Office to prepare by Order in Council the Dominion constitution of Sri Lanka.

${ }^{41}$ The idea of a judicially enforceable bill of rights was alien to the Diceyan spirit of British constitutionalism, and thus not a feature of New Dominion constitutions. But some British-led constitutional efforts had earlier included the incorporation of specific rights: e.g. the Government of India Act 1935 guaranteed property rights and protected against discrimination based on religion, place of birth, or color for the purposes of public sector employment, property rights, and access to a profession (sections 298 and 462).

${ }^{42}$ India's trend-setting role in this regard, and in respect to developing a bill of rights, is acknowledged in CHARLES O. H. PARKINSON, BILLS OF RIGHTS AND DECOLONIZATION 46 (2007).

${ }^{43}$ [1935] 1 I.R. 170.

${ }^{44}$ At first instance, Maulvi Tamizuddin Khan v. Federation of Pakistan, (1955) PLD 1955 (Sindh) 96; on appeal Federation of Pakistan and Others v. Maulvi Tamizuddin Khan, (1955) PLD (Federal Court) 240.

${ }^{45}$ An interesting point of contrast might be the development of rights jurisprudence and the principle of proportionality in post-War (West) Germany. See, e.g., JACCO BOMHOFF, BALANCING CONSTITUTIONAL RightS: THE ORIGINS AND MEANING OF POSTWAR LEGAL DISCOURSE ch. 3 (2013). 


\section{Severing of the legislative link:}

The basic text here was the Statute of Westminster 1931, passed after the imperial conferences of 1926-1930 to stabilize legal relations between various units of the Empire, and then reiterated in the various Independence Acts. From the metropolitan perspective, the Statute's self-limiting properties gave rise to a constitutional conundrum concerning the absolute nature of parliamentary sovereignty. ${ }^{46}$ But from a more cosmopolitan angle, the self-limiting of the Imperial Parliament was a pragmatic tool that operated to allow the selfgoverning polity to amend the Dominion constitution and draft the new permanent constitution on whatever terms it pleased.

\section{Retention of the executive link:}

The retention of an associational link to the Crown is a connection given expression in the office of the Governor General as Head of State appointed by the British monarch. ${ }^{47} \mathrm{~A}$ relic of the UK's monarchical tradition, the governorgeneral was expected to perform symbolic and ceremonial functions within the self-governing polity but often played an active role in constitutional politics, eluding the weak accountability mechanisms of Dominion constitutionalism. ${ }^{48}$ For instance, the governor-general of Pakistan (allied with the developing bureaucratic-military axis) used his prerogative powers to dissolve that country's first Constituent Assembly, whereas in India Lord Mountbatten, as governorgeneral, acquiesced in the government's decision to retain draconian laws that

\footnotetext{
${ }^{46}$ See British Coal Corporation v. The King, [1935] A.C. 500, 520-522, discussed in Peter C. Oliver, "Dominion Status": History, Framework, and Context, 17(4) INT'L J. CONST. L. (2019). For more on that conundrum, see another seminal Privy Council case arising from a decolonizing context of a slightly later vintage: Madzimbamuto v. Lardner-Burke, [1969] A.C. 645.

${ }^{47}$ For analysis of what became an incredibly complex area of jurisprudence, see Anne Twomey, Responsible Government and the Divisibility of the Crown, (PUB. L. 742 (2008). The question continues to bedevil UK courts. See R (Quark Fishing Ltd) v. Secretary of State for Foreign and Commonwealth Affairs, [2005] U.K.H.L. 57; R (Bancoult) v Secretary of State for Foreign and Commonwealth Affairs (No. 2), [2008] U.K.H.L. 61; Keyu v. Secretary of State for Foreign and Commonwealth Affairs, [2015] U.K.S.C. 69.

${ }^{48}$ Anne Twomey, Discretionary Reserve Powers of Heads of State, in CONSTITUTIONMAKING IN ASIA 55 (Harshan Kumarasingham ed., 2016).
} 
enabled the quashing of dissent. The semblance of an ongoing linkage between the national government and the British Crown also proved useful in India in a different way, facilitating the assimilation of the princely states within the new state structure. From the British perspective, the link to the Crown was instrumental in retaining the Dominions within the Commonwealth and within the British sphere of influence.

\section{Retention of the judicial link:}

The retention of the Joint Committee of the Privy Council, the old imperial court, as the highest court of appeal when Dominion status was granted, was deemed essential by the British but considered highly problematic by independence leaders. This jurisdiction was brought to an end within a few years of independence in Ireland, India, and Pakistan, though it was retained in Ceylon until the new republican constitution (of Sri Lanka) was adopted in 1972. But even in jurisdictions that severed the link with the Privy Council, forms of transnational constitutional dialogue endured as local courts found themselves interpreting the Dominion constitution in light of both the common law and postindependence legal developments.

\section{Lack of roadmap for constitutional transition:}

New Dominion constitutions, notwithstanding the fact that they were conceived as transitional, all featured a vague or non-existent legal framework for drafting the permanent constitution. As a platform for transitional constitutionalism, the New Dominion model is thus noteworthy for its lack of specific transitional arrangements for constitution making. Or, rather, the arrangements it made tended to be institutional or structural rather than legal or substantive. The absence of a blueprint for constitution making may have facilitated national ownership of the independent constitution as the various drafting processes could be seen as autochthonous even if they involved input from non-nationals. By the same token, however, being essentially bargains between the British and local leaders, Dominion constitutions were virtually silent on the balance of power among local elites that the new constitution might reflect. We can see this vagueness as the external manifestation of a style of (political) constitutionalism 
that dominated the British constitutional thought of the period. Otherwise divergent writers like Dicey and Jennings could agree that constitutions were ideally flexible and political, with most matters left open for parties operating in a robust institutional context and within a matrix of sufficiently agreed upon conventions to resolve. Exported to New Dominion settings, the flexible and political became ambiguous and diplomatic, a situation which the absence of either well-grounded institutions or sufficiently agreed upon conventions made ripe for exploitation.

\section{Constitutional ambiguity and versatility:}

An emphasis on evolution and managed change, admittedly more implicit to New Dominion constitutions than textual, gave enormous leeway to local political leaders. The enduring belief in the value of open-textured constitutions and the virtue of ambiguity seems to be have been predicated on the notion that elites, both local and British, could work together to secure a harmony of interests between metropolitan interests and those of the self-governing polity. So understood, New Dominion constitutionalism becomes an elaboration of an essentially eighteenth-century constitutional philosophy. According to Burke's canonical statement, constitutions were fundamentally moral orders that served ideally to iron out discontinuities between past and present and to find an overarching balance capable of transcending potential conflict between social orders. Dominion status was thus a "constitutional laboratory" that remained peculiarly open to the contextual specificities of the various jurisdictions, a feature of the model that helps to explain the diverse trajectories identified in our case studies. It should not be forgotten that the experiences that took place under the New Dominion umbrella occurred in deeply divided polities and might usefully be understood as instances of what Hanna Lerner calls the incrementalist approach to constitution making. ${ }^{49}$

\section{Acquisition of external sovereignty:}

We tend to think about the decolonization process from the legal angle in terms of the movement from subjection to sovereignty. While this is the most important

\footnotetext{
${ }^{49}$ HANNA LERNER, MAKING CONSTITUTIONS IN DEEPLy DiVIDED SOCIETIES (2011).
} 
and obvious consequence of decolonization it is not the only one. Decolonization can also be conceived in terms of a reconfiguration of patterns of international association. Previous terms of association were structured by the imperial power. The nature of those terms varied depending on the period, but certainly within the old Empire conduct and responsibility of foreign policy lay exclusively with the British government. ${ }^{50}$ Even later, supposedly "free" association revolved around a series of (lopsided) pacts within the intra-imperial network of territories. ${ }^{51}$ Accrual of New Dominion status entailed a new international standing, entitling the former colony to membership of a different club. Recognized as a full international legal agent, ${ }^{52}$ the newly independent state was now in principle free to exercise its capacities as a responsible member of the international legal community.

\section{Achievements and drawbacks of New Dominion constitutional ism}

So was New Dominion constitutionalism a failure? The variety of the national independence trajectories in our four case studies makes it hard to draw general conclusions, and "success" in this context is difficult to define with any precision. ${ }^{53}$ At least in an attenuated and technical sense, all our case studies are stories of success' since the Dominion model was adopted in these jurisdictions, albeit sometimes only for a short interval. In other parts of the Colonial Empire, Dominion status was rejected outright. The most notable contemporary example is Burma, which became a republic

\footnotetext{
${ }^{50}$ For an intriguing contemporary analysis of the complex transitional arrangements in the interwar or "Old" Dominion era, see William Harrison Moore, The British Empire in Foreign Policy, 5 Australian Q. 3 (1933).

${ }^{51}$ For analysis of the challenges in defining this wider association See, e.g., R. Bright \& A. Dilley, After the British World, 60 THE HISTORICAL JOURNAL 547-568 (2017).

52 India had exercised some legal capacity in the international sphere before independence. It was a founder member of the United Nations, joining in October 1945, as it had been of the League of Nations. It had earlier had semi-independent status in the Paris Peace Conference of 1919, headed by the Secretary of State for India, Edwin Montagu, and two Indian members, Lord Sinha and the Maharjah of Bikaner: MARGARET MACMILLAN, PEACEMAKERS 56 (2001).

${ }^{53}$ Although up until the mid-1960s, the Foreign Office kept a balance sheet of postindependence success and failures at least in east Africa. A. M. Palliser, Policy towards East Africa, Top Secret, Feb. 4, 1964, FO 371/176524, quoted in Louis, supra note 27, at 350 .
} 
in 1948 without passing through the Dominion stage and promptly left the Commonwealth. During the 1950s and 1960s other former colonies, such as Sudan, took a similar path, something we reflect upon later when considering the legacy of New Dominion constitutionalism.

More substantively, we might note that while the transition from colonial territory to autonomous Dominion to fully sovereign state was not always achieved without violence, most obviously so in respect of the partition of India, the New Dominion model had some success in ushering various participants relatively peacefully along the path to independence. ${ }^{54}$ But even if we are inclined to accept this claim, the case studies also suggest that the price paid for peace was the ceding by the British of any residual authority to local elites much faster than they intended or had predicted. This central theme - of British failure, or at least the way things slipped very quickly from British control-emerges strongly from the case studies. Moreover, the substantial widening of the club of self-governing Dominions beyond the "Old" Dominion model largely emptied the category of substance while also threatening the associational potential of the New Commonwealth order. Subsequent proliferation of Dominions, Commonwealth Realms, and independent Republics meant not only the dissolution of the British Empire but also the final demise of old dreams of global order centered on British domination, a point reinforced by the Suez debacle of 1956.

But we need to add another piece to our evaluative picture: in the period that we are considering the dismembering of the British Empire became inextricably intertwined with the Cold War. ${ }^{55}$ As the Cold War heated up in Asia with the success of the Communist Revolution in China in 1949 and the outbreak of the Korean War in

\footnotetext{
54 The late-imperial wars, conflicts, and breaches of the peace have tended to be rather marginalized. Interestingly, recent court cases have raised questions of the mistreatment of subject peoples from this era in both Malaya/Malaysia and Kenya. See Keyu v. Secretary of State for Foreign and Commonwealth Affairs, [2015] U.K.S.C. 69, discussed in Thomas Poole \& Sangeeta Shah, A Very Successful Action? Keyu and Historical Wrongs at Common Law, 7 UK SUPREME COURT Y.B. 167 (2016); Ndiku Mutua and Others v. The Foreign and Commonwealth Office, [2011] E.W.H.C. 1913 (QB) and [2012] E.W.H.C. 2678 (QB), discussed in Devika Hovell, The Gulf Between Tortious and Torturous: UK Responsibility for Mistreatment of the Mau Mau in Colonial Kenya, 11 J. INT'L CRIM. JUST. 223 (2013).

${ }^{55}$ Leslie James \& Elisabeth Leake, Introduction, in DECOLONIZATION AND THE COLD WAR: NEGOTIATING INDEPENDENCE 2 (Leslie James \& Elisabeth Leake eds., 2015).
} 
1950, South Asia acquired crucial importance. It became a strategic imperative to retain the newly independent states of the Indian subcontinent within the US-dominated, Western sphere of influence. The British aimed to further Western interests in the region by influencing the constitution-making processes, and even constitutional litigation, in the decolonizing states — witness British jurist Sir Ivor Jennings's work as a constitutional consultant not only in Sri Lanka and Pakistan but also Malaya, the Maldives, and Nepal at key transitional moments. ${ }^{56}$

Our case studies indicate that the New Dominion model had mixed success in achieving this goal. Shortly after independence, India turned towards the Soviet Union and co-founded the Non-Aligned Movement, whereas in 1954 Pakistan became the foremost Western ally in the region as a member of SEATO (the Asian equivalent of NATO). As such, Britain's attempts to 'lock in' influence while ceding control through the New Dominion constitutional framework were to a great extent unsuccessful.

\section{Conclusion: Legacies of New Domini on constitutionalism}

From the perspective of the New Dominions, the legacy of this transitional constitutional framework remains evident in post-independence constitutional design and practice across the case studies and helps explain the different constitutional trajectories of these countries after independence. Moreover, while Dominion status in Ireland, India, Pakistan, and Sri Lanka represented an important stage in the constitutional development of these nations, the historical elision of the New Dominion period in the national consciousness is all the more significant. In some of these jurisdictions, this seems to reflect a deliberate, almost official, policy of minimizingeven forgetting - that a transitional phase had ever occurred. If we understand New Dominion framework as an instrument of state-building for the various decolonizing

\footnotetext{
${ }^{56}$ M. Malagodi, Ivor Jennings' Constitutional Legacy Beyond the Occidental-Oriental Divide, 42 J. L. \& SoC'Y 102 (2015); J. M. Fernando, Constitutionalism and the Politics of Constitution-Making in Malaya, 1956-1957, in CONSTITUTION-MAKING IN ASIA 137 (Harshan Kumarasingham ed., 2016); Mara Malagodi, Constitution Drafting as Cold War Realpolitik: Sir Ivor Jennings and Nepal's 1959 Constitution, in CONSTITUTIONMAKING IN ASIA 154 (Harshan Kumarasingham ed., 2016). See also IVOR JENNINGS, THE DOMINION OF CEYLON: THE DEVELOPMENT OF ITS LAWS AND CONSTITUTION (1952).
} 
nations, the forgettable quality of the constitutional order that it instantiated may be seen as a useful, perhaps even virtuous, quality of this mode of transitional constitutionalism. This semi-deliberate strategy of "forgetting" may be seen as an important way in which each country sought to overcome the "sovereignty deficit" at the heart of the New Dominion constitution-making process, a consequence of their origins as legal texts crafted largely by the imperial center whose formal authority derived from an Act of the Imperial Parliament. While Ireland sought to escape the neocolonial nature of Dominion status by avoiding the imposition of a constitutional settlement by the imperial center by drafting the constitution by itself and having it rubber-stamped by an Act of the Imperial Parliament, even this did not suffice and a new document was enacted in 1937; meanwhile, the South Asian Dominions faced a greater legitimacy deficit with regard to their constitutional transition to independence.

The incrementalist features of New Dominion constitutions had other ramifications, not all of them so sanguine. Most notably, the open-textured nature of those constitutions and the many silences they contained made it easier for local elites to determine the institutional and normative structures of the new state. Nonprescriptive New Dominion constitutional arrangements may have facilitated the genesis of new independent constitutions. But they could also be exploited by local leaders in order to consolidate their position and sideline political rivals. It may not be a coincidence that the subsequent republican constitutions of the jurisdictions studied in this special issue featured dominant executives, and that Pakistan and Sri Lanka both saw recurring bouts of authoritarian rule.

The length of the transition out of Dominion status also had a bearing on postindependence constitutional development. The case studies indicate that short transitional periods may have helped to conflate the somehow "post-sovereign" constitutional birth of the nation with full independence. ${ }^{57}$ India, for example, moved quickly to instantiate a Constituent Assembly, that quintessential expression of sovereign constituent capacity. In Ireland, the dangers associated with a lengthy transition may have been mitigated by the ability of the Third Dáil to lead the constitution-making process and harness its long-term legitimacy. But in Pakistan and

\footnotetext{
${ }^{57}$ ARATO, supra note 1.
} 
Sri Lanka, the potential energy associated with the "constitutional moment" of independence gradually dissipated, resulting in successive bouts of authoritarian constitutionalism..$^{58}$

There is an argument to be made that the central institutional legacy of New Dominion constitutions was aversive in another, and broader, sense. More specifically, the legal side of the permanent constitutions adopted in most of the jurisdictions in our study owed relatively little to the Westminster template that provided if not the detail then certainly the normative mood music of the New Dominion constitutional style. Ireland, India, and Pakistan were to adopt entrenched constitutions featuring extensive and justiciable fundamental rights, a substantial departure from the New Dominion template. What has been said in respect of the Indian practice with regard to rightsthat it "owed little to British influence, drawing instead on the bills of rights in the American, French and Irish constitutions" ${ }^{29}$-would also seem to apply to these other nations. Granville Austin explains the central importance of the judiciary in the framing of India's independent constitution:

The members of the Constituent Assembly brought to the framing of the Judicial provisions of the Constitution an idealism equaled only by that shown towards the Fundamental Rights. Indeed, the Judiciary was seen as an extension of the Rights, for it was the courts that would give the rights force.... The courts were also idealized because, as guardians of the Constitution, they would be the expression of the new law created by Indians for Indians. During the British period, despite the presence of Indians in government, Indians had not been responsible for the laws that governed them. Indians had neither law nor courts of their own, and both the courts and the law had been designed to meet the needs of the colonial power. Under the Constitution, all this would be changed. The courts were, therefore, widely considered one of the most tangible evidences of independence. ${ }^{60}$

\footnotetext{
${ }^{58}$ MARK TUSHNET \& MADHAV KHOSLA (EDS.), UNSTABLE CONSTITUTIONALISM. LAW AND POLITICS IN SOUTH ASIA (2015).

${ }^{59}$ C. Parkinson, British Constitutional Thought and the Emergence of Bills of Rights in Britain's Overseas Territories in Asia at Decolonisation, in CONSTITUTION-MAKING IN ASIA 41 (Harshan Kumarasingham ed., 2016).

${ }^{60}$ GRANVILLE AUSTIN, THE INDIAN CONSTITUTION: CORNERSTONE OF A NATION (1966).
} 
Pakistan sought to emulate the Indian model and to enshrine legal checks on executive power in the first 1956 republican constitution, but the military coup of 1958 soon brought that constitutional experiment to an end. Sri Lanka stayed truer to the (old) Westminster tradition of non-justiciable rights and limited judicial review. But this remains one of the most contentious features of its constitutional arrangements and a source of demands for structural reform. In this respect, it remains difficult to assess the link between New Dominion constitutionalism and the political trajectories of the four case studies after independence, especially with regard to democratization.

Finally, the experience of New Dominion constitutionalism helped shape the modality of decolonization of the remaining colonies and dependencies of the British Empire. In retrospect, the year 1949 represents a watershed: within ten days in April Ireland became a Republic and left the Commonwealth, while India remained in the Commonwealth as a Republic. These changes equated with a new supranational role for the Crown and in the associational basis of the Commonwealth. As a result, the 1949 Conference produced what is known as the London Declaration: "the King is the symbol of the free association of its independent members and as such the Head of the Commonwealth," ${ }^{61}$ a formulation which found legal expression in the Royal Titles Act 1953. In order to cement that new statutorily enshrined relationship of equality among Commonwealth members, it was felt that the term "Dominion" ought to be discarded. Gordon Walker, MP, expressed this widely held sentiment when he said in the parliamentary debate on the Act in 1953:

I welcome the disappearance of the words "Dominions beyond the seas", which, I hope will mark the formal disappearance of the word "Dominions" from the vocabulary of the Commonwealth. This word is disliked in many parts of the Commonwealth because it suggests a distinction of status between the United Kingdom and other parts of the Commonwealth. The words "other Realms" in the title will give the word "realm" a greater currency than it has today, and it is a more

${ }^{61}$ McIntyre, supra note 9, at 202. 
acceptable word. ${ }^{62}$

The expression "Commonwealth Realm" came to substitute for the term "Dominion," and technically both Pakistan and Ceylon became Commonwealth Realms in 1953 before they became Republics in 1956 and 1972, respectively. But the substance of the transitional constitutional arrangements created under New Dominion status remained largely unchanged - the majority of British colonies from the 1950s onward continued to acquire independence by constitutional means that were in most respects the same as those deployed earlier on in the South Asian Dominions. ${ }^{63}$ Former British colonies in this period obtained "fully responsible status within the Commonwealth" on the basis of Independence Acts passed by Westminster adhering to a pattern of constitutional arrangements that, although they might now fall under the rubric of Commonwealth Realm, clearly derived from New Dominion constitutionalism. ${ }^{64}$ In fact, after 1949, as the term "Dominion" fell into disuse, the majority of British former colonies and dependencies still adopted transitional constitutional frameworks similar to the New Dominion constitutional model.

On this point, it is interesting that only a small number of decolonizing nations regarded the option of a transitional constitutional deal as an unsuitable or unnec essary accompaniment on the path to independence. Malaya became independent in 1957, for instance, but remained a Commonwealth member as an "independent sovereign country within the Commonwealth" under the Federation of Malaya Independence Act 1957. Northern Rhodesia (later Zambia) and the Bechuanaland Protectorate (later Botswana) followed the same pattern and became republics in 1964 and 1966, respectively, while

\footnotetext{
${ }^{62}$ Hansard HC Deb 03 March 1953 Vol. 512 cc 193-257. Walker, son of a Scottish judge in the Indian Civil Service, had served as Parliamentary Under-Secretary of State at the Commonwealth Relations Office and then as Secretary of State for Commonwealth Relations in the Labour government of 1945-1951. He was later to serve as Foreign Secretary under Harold Wilson.

${ }^{63}$ Supra note 7.

64 An analysis of "Commonwealth Realm" constitutionalism as a transitional and transnational constitutional mold to facilitate decolonization after New Dominion constitutionalism fell into disuse is beyond the scope of this article, but it remains an area of constitutional history worth exploring in a comparative fashion.
} 
still retaining Commonwealth membership.

Yet, while there is a great deal of legal continuity between the New Dominion model and the later Commonwealth Realms, by the 1960s it became clear that the Commonwealth was not what the British had intended it to be after World War II. For the British, the New Dominion transitional model had represented a global attempt to combine the earlier idea of imperial national ism with a new vision of a strong, Britannic Commonwealth held together by bonds of affection. It did not take long for this Britannic Commonwealth dream to be revealed as little more than an imperial fantasy. The reality of the Commonwealth of Nations became that of a diverse, loose, and largely symbolic association of independent states. The case studies in this symposium demonstrate why the New Dominion model did not achieve what British politicians and jurists had intended: the British aim of retaining a measure of control over newly independent former colonies could not be reconciled with the goals of local actors, to whom sovereignty had undisputedly passed, and who made use of the transitional New Dominion model to enshrine new state institutions and structures, and to push for full independence from Britain. 